\title{
Multiple advances of Alpine glaciers into the Jura Mountains in the Northwestern Switzerland
}

\author{
Angela Graf ${ }^{1} \cdot$ Naki Akçar $^{2} \cdot$ Susan Ivy-Ochs ${ }^{3} \cdot$ Stefan Strasky $^{4} \cdot$ Peter W. Kubik $^{3}$ • \\ Marcus Christl $^{3} \cdot$ Martin Burkhard $^{5} \cdot$ Rainer Wieler $^{4} \cdot$ Christian Schlüchter $^{2}$
}

Received: 2 July 2014/Accepted: 26 July 2015/Published online: 29 August 2015

(C) Swiss Geological Society 2015

\begin{abstract}
To reconstruct the timing of Alpine glacier advances onto the Jura Mountains, we sampled 17 Alpine erratic boulders within and beyond the LGM (Last Glacial Maximum) extent of the Valais Glacier along three transect for the analysis of cosmogenic ${ }^{10} \mathrm{Be}$. Our results indicate at least two advances into the study area in Northwestern Switzerland; one during the LGM and one beforehand. Reaching of the maximum extent of by the Valais Glacier into the Jura mountains during the LGM occurred at $21.9 \pm 1.8 \mathrm{ka}$ based on erratic boulders exposure ages. Ages of boulders located beyond the LGM extent of the Valais Glacier vary from $19.9 \pm 1.6$ to $144.0 \pm 9.6 \mathrm{ka}$. These ages indicate that many of the boulders were displaced and re-deposited by local ice in the Jura Mountains both during and perhaps even prior to the LGM. Therefore, the chronology of the pre-LGM advance(s) of Alpine glaciers into the Jura Mountains remains still to be elaborated.
\end{abstract}

Keywords Surface exposure dating - Foreland - Valais . Rhone $\cdot$ Cosmogenic ${ }^{10} \mathrm{Be} \cdot \mathrm{LGM}$

Naki Akçar

akcar@geo.unibe.ch

1 Geologische Beratungen Schenker Korner + Partner GmbH, Büttenenhalde 42, 6006 Lucerne, Switzerland

2 Institute of Geological Sciences, University of Bern, Baltzerstrasse 1-3, 3012 Bern, Switzerland

3 Laboratory of Ion Beam Physics (LIP), ETH Zurich, 8093 Zurich, Switzerland

4 Institute of Isotope Geochemistry and Mineral Resources, ETH Zurich, Clausiusstrasse 25, 8092 Zurich, Switzerland

5 Institute of Geology, Neuchâtel University, Rue EmileArgand 11, 2007 Neuchâtel, Switzerland

\section{Introduction}

During the last glacial maximum (LGM; $22.1 \pm 4.3 \mathrm{ka}$ sensu Shakun and Carlson 2010), large ice-masses accumulated in the European Alps and drained predominantly by ice streams through the large longitudinal valleys, but also formed a radial network of ice transfluences across major passes and lower cols. These then evolved into piedmont glaciers that overrode the Alpine Foreland, namely the Valais, Aare, Reuss, Linth and Rhaetian Glaciers (Fig. 1; Florineth and Schlüchter 1998; Kelly et al. 2004; Bini et al. 2009). The Valais ice accumulated mainly in the Mattertal Ice Plateau, Rhone Ice Dome and the southern Valaisian Alps (Bini et al. 2009 and references therein). The ice stream flowing northwards from the Mattertal Ice Plateau blocked the ice from the Rhone Ice Dome in the upper Rhone Valley and forced it to flow southwards and over the Simplon Pass. Therefore, the Valais Glacier stemmed from the $\mathrm{S}-\mathrm{N}$ trending tributary valleys between Visp and Martigny. This flow regime also explains the absence of erratic boulder lithologies from the upper Rhone Valley in the Swiss Midlands and the Jura Mountains (Bini et al. 2009 and references therein). The Jura Mountains, made of Mesozoic carbonates (Pfiffner 2009), formed a barrier perpendicular to the ice flow, thus forcing the Valais Glacier to divide into two lobes. One flowed westwards and was joined by the Arve glacier, ending ca. $20 \mathrm{~km}$ east of Lyon, while the other lobe flowed eastwards, merging with the ice of the Aare glacier and ending ca. $10 \mathrm{~km}$ east of Solothurn (Fig. 1; e.g., Ivy-Ochs et al. 2004). The last advance of the Alpine glaciers onto the Foreland is morphologically and chronologically well defined (Bini et al. 2009). For instance, the LGM advance of the Valais Glacier took place after $25^{\prime} 370 \pm 190{ }^{14} \mathrm{C}$ yr BP (30'062-28'931 cal BP; calibrated with OxCal 4.2; 


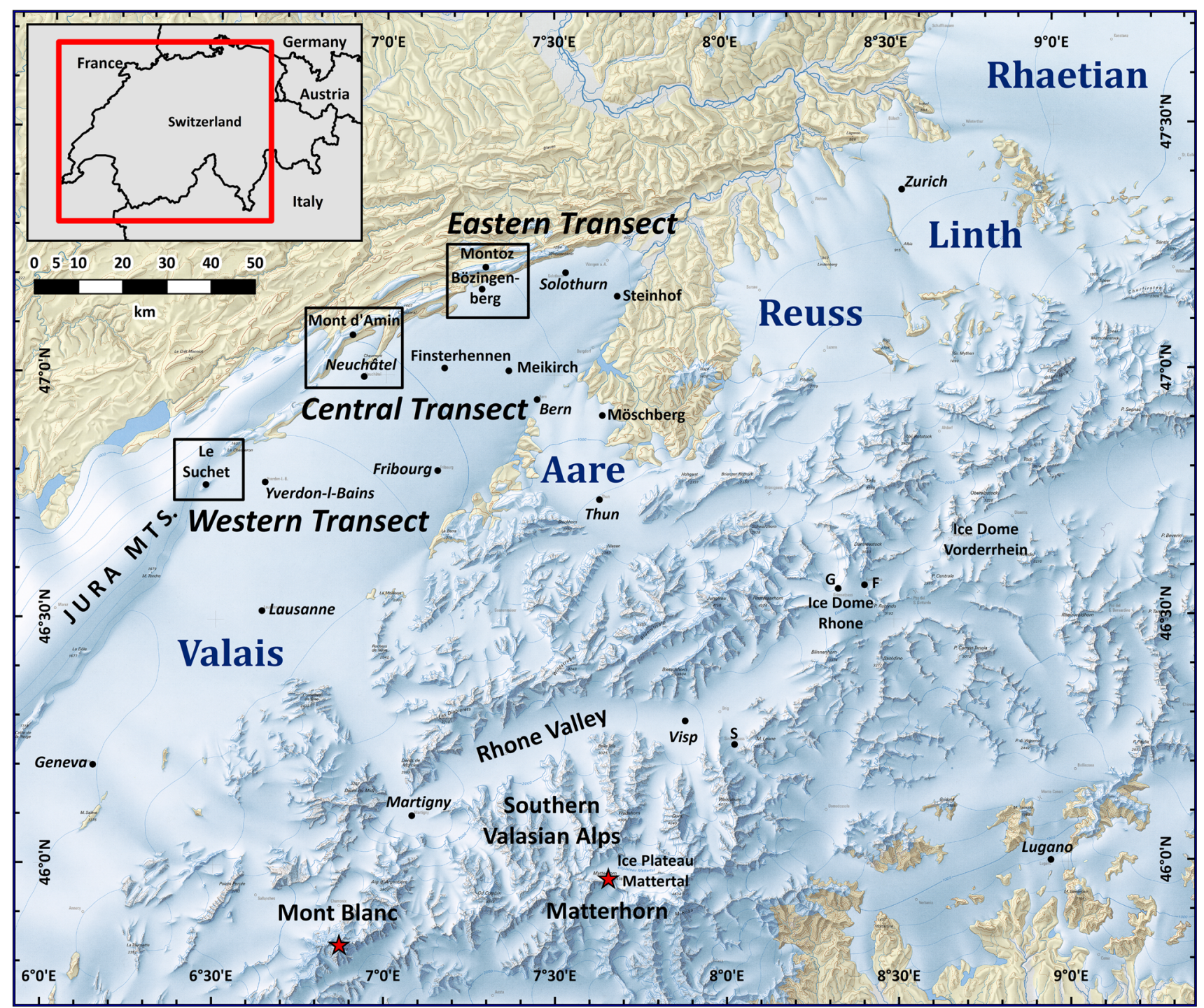

Fig. 1 Extension of the Valais, Aare, Reuss, Lindth and Rhaetian Lobes during the LGM (from Bini et al. 2009), locations of the studied transects. OFederal Office of Topography, swisstopo, CH-3084 Wabern. F: Furka Pass; G: Grimsel Pass; S: Simplon Pass

Bronk Ramsey 2009) based on a mammoth tusk embedded in the glaciofluvial sediments in Finsterhennen (Canton of Bern) (Schlüchter 2004) and OSL ages of $28.5 \pm 2.3$ and $28.9 \pm 2.5 \mathrm{ka}$ on these sediments (Preusser et al. 2007). Its maximum extent dated to $24.0 \pm 1.1 \mathrm{ka}$ (Steinhof, Canton of Solothurn) and $21.5 \pm 1.0 \mathrm{ka}$ (Möschberg, Canton of Bern) for the Aare Glacier $\left({ }^{10} \mathrm{Be}\right.$ exposure ages recalculated from Ivy-Ochs et al. 2004 and Akçar et al. 2011).

During the LGM, the Alpine ice flowed along the first anticline and penetrated into the low valleys of the Jura Mountains (Fig. 1). Beyond the LGM extent, erratic boulders of Alpine origin and relict tills are also found. These lines of evidence show that Alpine glaciers must have covered the Alpine Foreland and parts of the Jura Mountains once or several times prior to the LGM (e.g., Nussbaum and Gygax 1935). However both morphology and chronology of these pre-LGM glaciation(s) are poorly constrained in comparison to the LGM advance (cf. Preusser et al. 2011). According to their geographical distribution, altitude and relative freshness, the erratic boulders and tills have been either attributed to the "Würmian" (younger) or the "Rissian" (older) glacial extent in conformity with the classical model of Penck and Brückner (1909). In the eastern part of the Jura Mountains, the situation is further complicated by the presence of local ice caps during both glacial cycles (Aubert 1965; Nussbaum and Gygax 1935; Buoncristiani and Campy 2004a).

The majority of the erratic boulders on the carbonate bedrock of the Jura Mountains are granitic rocks from the Mont Blanc Massif and metamorphic rocks from the southern Valaisian Alps, including the Mattertal (Fig. 1). For instance, gabbros and eclogites from the zone Zermatt- 
Saas Fee and gneisses from the Dent-Blanche Nappe are abundant (Graf et al. 2007 and references therein). Most of the boulders were used as a building material or destroyed in addition to the post-depositional processes such as exhumation (Akçar et al. 2011 and references therein). Therefore, the distribution of these boulders represents a relict distribution rather than the original, which makes the reconstruction of the geomorphological context difficult and complicated, especially for the boulders beyond the LGM.

In this study, we focus on the glacier advances onto the Jura Mountains in order to reconstruct their timing and extent. This study has three goals: (1) to locate and identify the erratic boulders in the field mentioned in the literature along three $\mathrm{S}-\mathrm{N}$ transects in addition to the data set from the Montoz area (in Graf et al. 2007) (Fig. 1); (2) to constrain the deposition ages of these boulders and thus the timing of the advance(s) of the Valais Glacier onto the Jura Mountains; and (3) to provide a minimum age for deglaciation of these areas at the end of the last glacial cycle.

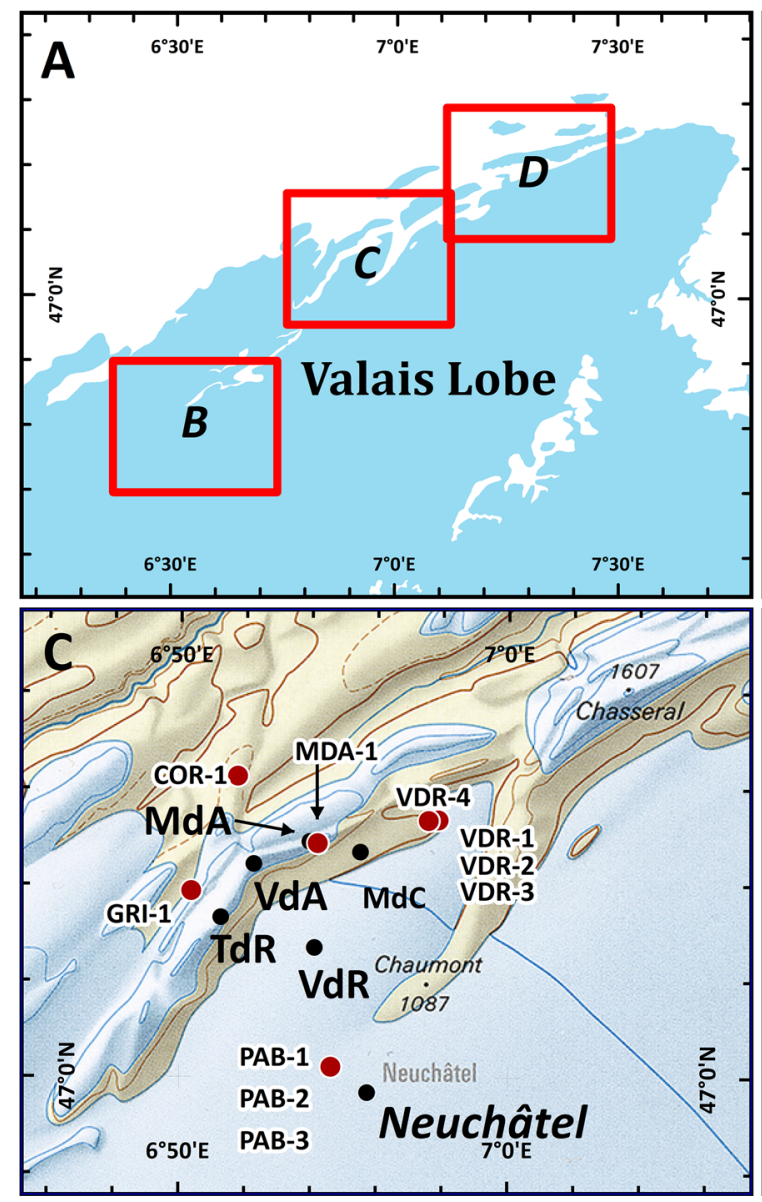

Fig. 2 a The Valais Lobe during the LGM (from Bini et al. 2009) and studied transects; b Eastern transect and sample locations; c Central transect and sample locations; and d Western transect and sample locations. CFederal Office of Topography, swisstopo, $\mathrm{CH}-$

\section{Sampling sites}

The eastern transect covers the Montoz anticline and the Bözingenberg Hill, south of Montoz (Fig. 2). Montoz anticline is an east-west trending elongated hill, located north of the front range of the Jura Mountain chain. Four Arolla-Gneiss boulders were already sampled from the Montoz ridge and analysed in previous studies (Ivy-Ochs et al. 2006; Graf et al. 2007). MO-04-01 is located on the northern slope of the ridge, MO-04-02 is close to the crestline and MO-04-03 and MO-04-04 are on the southern flank (Fig. 2; Table 1). The Bözingenberg Hill is situated within the LGM extent and covered by till from its summit to the eastern end (Antenen et al. 2004). Two boulders (RH-2 and RH-3c, Mont Blanc Granite), were sampled on this hill (Fig. 2; Table 1).

The central transect is located around Neuchâtel, where the LGM Alpine ice penetrated into the Val de Travers and the Val de Ruz, but did not flow over the Tête de Ran and Vue des Alpes Pass (Fig. 2). Thus erratic boulders beyond

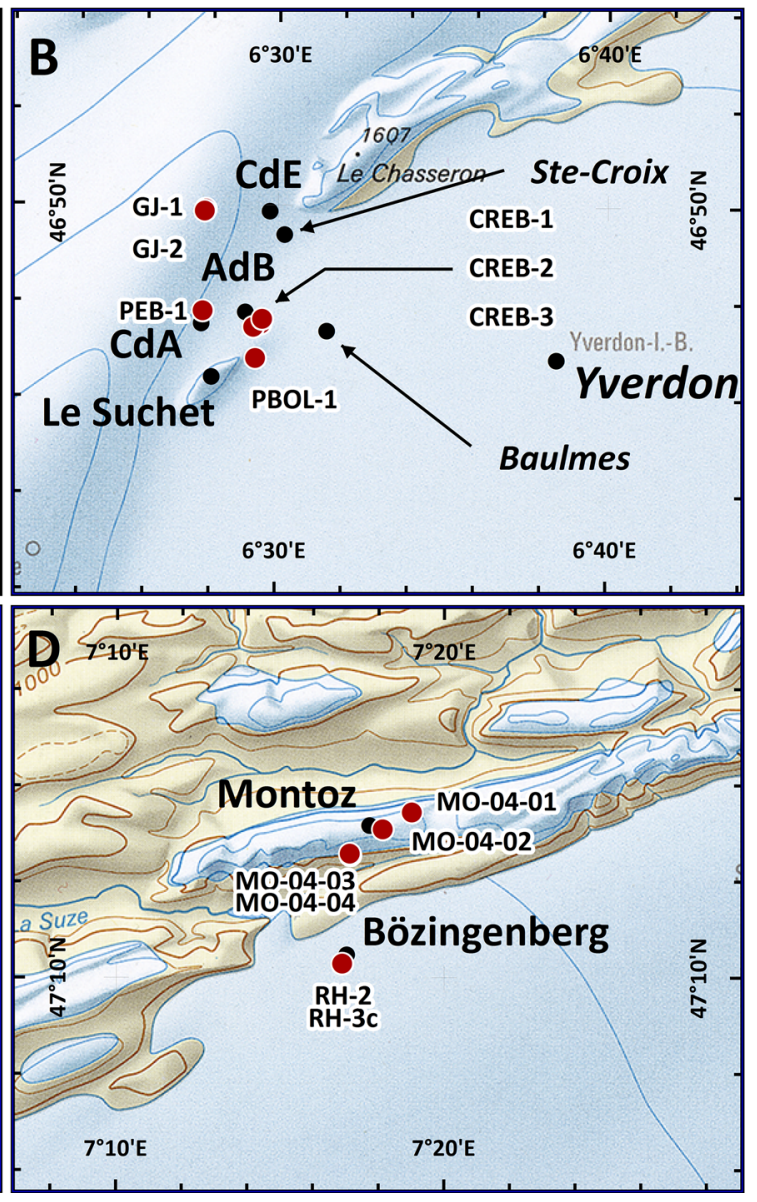

3084 Wabern. $A d B$ Aguilles de Baulmes, $C d A$ Col des Aiguillons, $C d E$ Col des Etroits, $M d A$ Mont d'Amin, $M d C$ Montagne de Chézard, $T d R$ Tête de Ran, $V d A$ Vue des Alpes, $V d R$ Val des Ruz 
Table 1 Description of samples from the Jura Mountains

\begin{tabular}{|c|c|c|c|c|c|c|c|c|}
\hline Sample name & Lithology & $\begin{array}{l}\text { Elevation } \\
\text { (m a.s.l.) }\end{array}$ & $\begin{array}{l}\text { Latitude, } \\
{ }^{\circ} \mathrm{N} \\
\text { (DD.DD) }\end{array}$ & $\begin{array}{l}\text { Longitude, } \\
{ }^{\circ} \mathrm{E} \\
\text { (DD.DD) }\end{array}$ & $\begin{array}{l}\text { Boulder } \\
\text { height }^{\mathrm{c}} \\
(\mathrm{m})\end{array}$ & $\begin{array}{l}\text { Sample } \\
\text { thickness } \\
(\mathrm{cm})\end{array}$ & $\begin{array}{l}\text { Thickness } \\
\text { correction } \\
\text { factor }^{\mathrm{d}}\end{array}$ & $\begin{array}{l}\text { Shielding } \\
\text { correction } \\
\text { factor }^{\mathrm{e}}\end{array}$ \\
\hline \multicolumn{9}{|c|}{ Eastern transect } \\
\hline MO-04-01 ${ }^{\mathrm{a}}$ & Arolla Gneiss & 1200 & 47.2240 & 7.3169 & 0.8 & 2 & 0.9836 & 0.9470 \\
\hline MO-04-02 & Arolla Gneiss & 1260 & 47.2181 & 7.3021 & 0.5 & 2 & 0.9836 & 0.9580 \\
\hline MO-04-03 ${ }^{\mathrm{a}}$ & Arolla Gneiss & 1050 & 47.2092 & 7.2856 & 1.8 & 2 & 0.9836 & 0.9360 \\
\hline MO-04-04 & Arolla Gneiss & 1060 & 47.2097 & 7.2854 & 1.7 & 2 & 0.9836 & 0.8920 \\
\hline RH-2 & Mt. Blanc Granite & 925 & 47.1718 & 7.2806 & 1.2 & 5 & 0.9597 & 0.9520 \\
\hline $\mathrm{RH}-3 \mathrm{c}$ & Mt. Blanc Granite & 928 & 47.1716 & 7.2816 & 2.0 & 5 & 0.9597 & 0.9520 \\
\hline \multicolumn{9}{|c|}{ Central transect } \\
\hline PAB-1 & Mt. Blanc Granite & 710 & 47.0037 & 6.9104 & 5.0 & 3 & 0.9756 & 0.9580 \\
\hline PAB-2 & Mt. Blanc Granite & 710 & 47.0037 & 6.9104 & 5.0 & 3.5 & 0.9716 & 0.9540 \\
\hline PAB- $3^{b}$ & Mt. Blanc Granite & 710 & 47.0037 & 6.9104 & 5.0 & 4 & & \\
\hline VDR-1 & Mt. Blanc Granite & 990 & 47.0893 & 6.9645 & 1.5 & 4 & 0.9676 & 0.9040 \\
\hline VDR-2 & Mt. Blanc Granite & 990 & 47.0893 & 6.9645 & 0.7 & 4 & 0.9676 & 0.9110 \\
\hline VDR-3 & Mt. Blanc Granite & 990 & 47.0893 & 6.9645 & 1.2 & 3 & 0.9756 & 0.9110 \\
\hline VDR-4 & Applite Mt. Blanc & 1010 & 47.0891 & 6.9595 & 1.2 & 3 & 0.9756 & 0.9110 \\
\hline MDA-1 & Crystalline & 1398 & 47.0812 & 6.9032 & 0.2 & 3 & 0.9756 & 0.9560 \\
\hline GRI-1 & Arolla Gneiss & 1090 & 47.0646 & 6.8392 & 1.7 & 3 & 0.9756 & 0.9390 \\
\hline COR-1 & Alallin Gabbro & 1160 & 47.1044 & 6.8625 & 1.0 & 4 & 0.9676 & 0.9550 \\
\hline \multicolumn{9}{|c|}{ Western transect } \\
\hline PBOL-1 & Mt. Blanc Granite & 1190 & 46.7803 & 6.4891 & 4.0 & 5 & 0.9597 & 0.9490 \\
\hline CREB-1 & Diorite & 1220 & 46.7922 & 6.4916 & 1.2 & 1 & 0.9918 & 0.9700 \\
\hline CREB-2 & Mt. Blanc Granite & 1257 & 46.7911 & 6.4880 & 1.8 & 1.5 & 0.9877 & 0.9560 \\
\hline CREB-3 & Mt. Blanc Granite & 1230 & 46.7939 & 6.4924 & 1.2 & 1 & 0.9918 & 0.9900 \\
\hline PEB-1 & Quartzite & 1245 & 46.7966 & 6.4623 & 0.6 & 5 & 0.9597 & 0.9600 \\
\hline GJ-1 & Quartzite & 1075 & 46.8319 & 6.4633 & 1.0 & 2 & 0.9836 & 0.9800 \\
\hline GJ-2 & Quartzite & 1079 & 46.8312 & 6.4628 & 0.3 & 2 & 0.9836 & 0.9300 \\
\hline
\end{tabular}

${ }^{a}$ Data from Graf et al. (2007)

b Sample from the bottom of the boulder

c Distance from the soil to the top of the boulder

${ }^{\mathrm{d}}$ Calculated for sample thickness with an uncertainty of $\pm 0.5 \mathrm{~cm}$ after Gosse and Phillips (2001), with mean attenuation length of $160 \mathrm{~g} / \mathrm{cm}^{2}$ and rock density of $2.65 \mathrm{~g} / \mathrm{cm}^{3}$

e Calculated for topographic shielding and dip of the surface after Dunne et al. (1999)

this pass must have been deposited by a pre-LGM glaciation. The first boulder sampled along this profile is the famous, more than $600 \mathrm{~m}^{3}$ Pierre-à-Bot, dedicated to the pioneer glaciologists Louis Agassiz, Arnold Guyot, Edouard Desor and Leon Dupasquier. This boulder is well embedded and, because of its huge size, post-depositional movement is excluded. Two samples from the upper surface (PAB-1 and PAB-2) and one sample from the bottom of the boulder (PAB-3) were taken to check for preexposure (Fig. 3a; Table 1). To the northeast, on Montagne de Chézard, four boulders from the Mont Blanc Massif were sampled (VDR-1 to VDR-4; Figs. 2, 3b; Table 1). Although these boulders were deposited almost $300 \mathrm{~m}$ above the Pierre-à-Bot, they are mapped within the limits of the last glaciation, and should thus indicate here the maximum position of the Alpine ice during the LGM. At $1398 \mathrm{~m}$ a.s.1. on Mont d'Amin, the highest pre-LGM erratic boulder of the Jura Mountains (Hantke 1978) was sampled (MDA-1; Fig. 2; Table 1). This small boulder is broken into two parts. Its lithology is very uncommon, composed of elongated, slightly metamorphosed silt clasts and quartz pebbles. As it looks more like a breccia, it cannot be correlated with the Carboniferous Vallorcine conglomerate of the southern Rhône Valley, and the provenance of this boulder has not yet been defined. Beyond the Vue des Alpes Pass, the erratic boulder "Le Grison" (GRI-1) was sampled in the upper end of the Val de la Sagne. The valley floor is boggy and mapped as "Rissian" till and it is known that peat has been mined. "Le Grison" is Arolla gneiss. The last and farthest erratic boulder sampled along this transect was "Le Cornu" (COR-1) (Fig. 2; Table 1). This arkesine rock has an impressive horn-shaped morphology and lies close to a pasture wall and a slope failure. It was not possible to locate the other erratic boulders that have been mapped by Bourquin et al. (1946). 

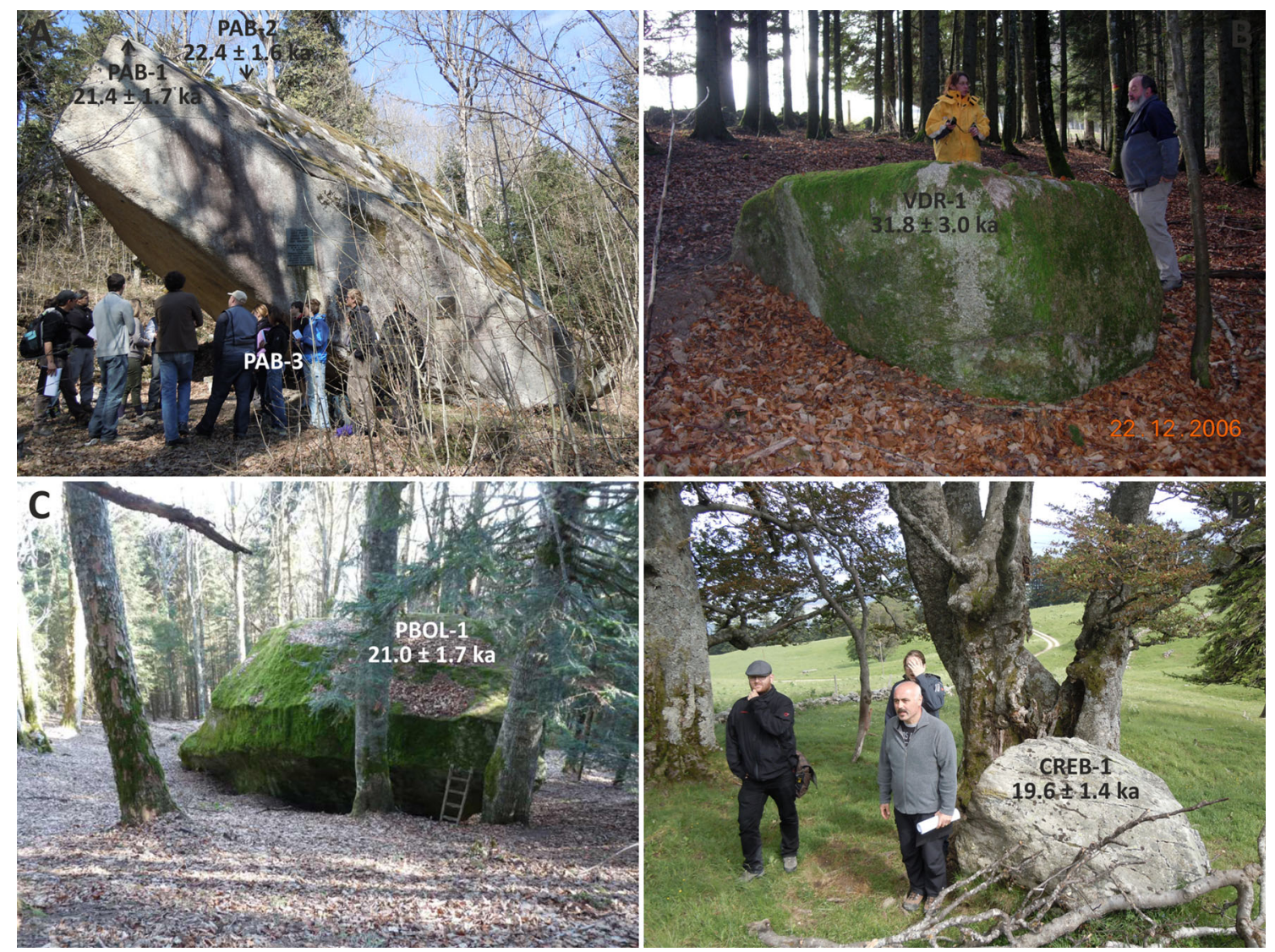

Fig. 3 Sampled boulders in the central and western transects. a Pierre-à-Bot in Neuchâtel; b VDR-1 in Val de Ruz; c Pierre-à-Bolet on the southern flank of Mont Suchet; d CREB-1 on the northern flank of Mont Suchet

The western transect is located to the west of Yverdon les Bains, and starts north of Baulmes (Figs. 1; 2). In this area, the LGM ice extended up to $1200 \mathrm{~m}$ asl on both sides of the Suchet, but did not flow over the Col des Aiguillons. Alpine ice also reached the area of St- Croix, but did not flow over Col des Etroits. This implicates that the erratic boulders found beyond the two passes should be of preLGM age. The anchor point of the western transect is the $300 \mathrm{~m}^{3}$ large Pierre-à-Bolet (Fig. 3c), on the southern flank of Mont Suchet. This Mont Blanc granite is well embedded in the basal till that covers part of the Mont Suchet, but displays traces of quarrying on its southwestern side; its original size is estimated to be at least one-third larger. It consists of such a hard rock-type that only one sample could be taken from the top. On the northern flank of Mont Suchet, a steep valley leads from the town of Baulmes to the Col des Aiguillons. The floor of this valley is covered by till with Alpine cobbles. Three erratic boulders near the Crébillons Alpine farmhouse were sampled (Fig. 2; Table 1). Two of these are Mont Blanc granites (CREB-2 and CREB-3), whereas the third (CREB-1) is a diorite and displays traces of quarrying on its eastern side (Fig. 3d). Beyond the Col des Aiguillons, where the Alpine ice of the last glaciation did not penetrate, the boulder Pierre d'en Bas (PEB-1) was sampled (Fig. 2; Table 1). The 75-cmhigh quartzite lies on the side of a small, unconsolidated forest track. Its position and size do not make it an ideal sample, but it was the only one found in this area. Two more quartzite boulders near Granges-Jaccard, north of the Col des Etroits were also sampled (Fig. 2; Table 1). The first boulder (GJ-1) is $1.1 \mathrm{~m}$ high, the second (GJ-2) only $0.4 \mathrm{~m}$. The latter is part of a group of smaller Alpine boulders embedded in the grassland.

\section{Methodology}

Along the three transects, 17 erratic boulders, standing from 0.2 to 5.0 meters above the surrounding ground, were sampled in addition to four previous samples (MO-04-01 to 04) from Graf et al. (2007). 18 surface samples from boulder tops and one from boulder bottom were collected with a hammer and chisel following previously published sampling strategies (e.g., Akçar et al. 2011). Sample information is given in Table 1. Samples were prepared at the Surface Exposure Dating Laboratory of the University 


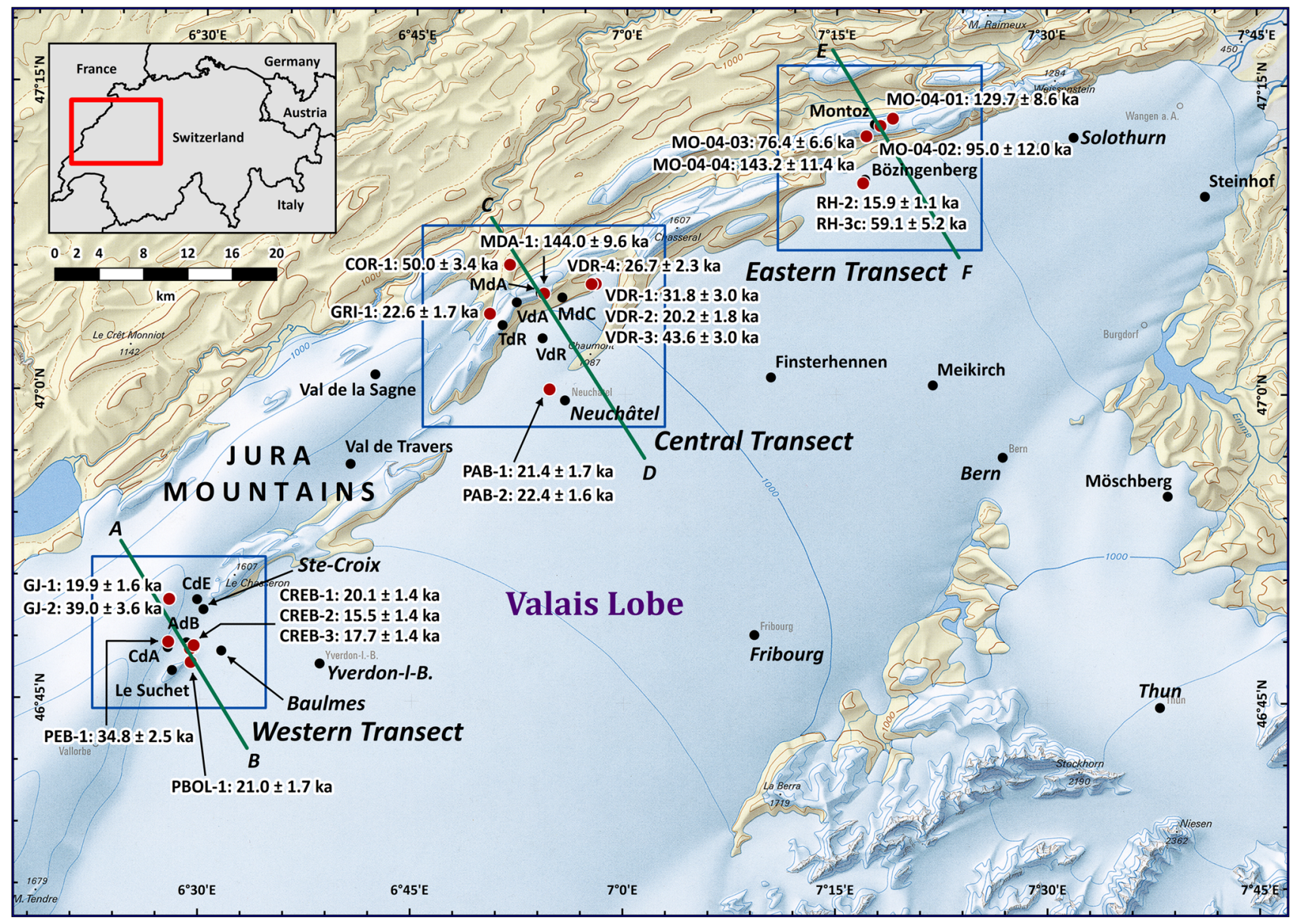

Fig. $4{ }^{10} \mathrm{Be}$ exposure ages from studied transect. Note that the uncertainties reported are external errors. Topographic profiles in Fig. 5 along each transect are also indicated. Please refer to the caption of the Fig. 2 for the abbreviations

of Bern. $40-50 \mathrm{~g}$ quartz were extracted and purified following a modified version of the technique introduced by Kohl and Nishiizumi (1992), Akçar (2006). A spike of $0.3 \mathrm{mg}$ of ${ }^{9} \mathrm{Be}$ was added to the samples. These were completely dissolved and fumed off before beryllium was extracted (Akçar 2006; Graf 2008). Four samples were processed in a batch, and each batch was accompanied by one full-process blank. The beryllium extract was then baked and pressed into copper targets. The ratio of ${ }^{10} \mathrm{Be} /{ }^{9} \mathrm{Be}$ was measured at the ETH tandem facility in Zurich (Synal et al. 1997). As these samples were processed and measured before April 2010, concentrations reported in this study were then referenced to the AMS standard 07KNSTD (Kubik and Christl 2010). A weighted mean ${ }^{10} \mathrm{Be} /{ }^{9} \mathrm{Be}$ full process blank ratio of $(2.36 \pm 0.10) \times 10^{-14}$ was applied. The cosmogenic nuclide data for the samples are given in Table 2 .

The CRONUS-Earth online calculator by Balco et al. (2008; http://hess.ess.washington.edu/math/) was used for the calculation of ${ }^{10} \mathrm{Be}$ exposure ages (including already published data in Graf et al. 2007) choosing the NE North American production rate calibration dataset (Balco et al.
2009; and wrapper script 2.2, main calculator 2.1, constants 2.2.1 and muons 1.1). A rock density of $2.65 \mathrm{~g} / \mathrm{cm}^{3}$ was applied. ${ }^{10} \mathrm{Be}$ exposure ages were corrected for the shielding by the surrounding topography (based on Dunne et al. 1999), the thickness of the sample (using an exponential attenuation length of $\left.160 \mathrm{~g} / \mathrm{cm}^{2}\right)$ and the erosion $(0.1 \mathrm{~cm} / \mathrm{ka}$ based on André 2002). No corrections were made for snow or vegetation in the age calculations. Based on the evaluation by Balco et al. (2009), the effect would be on the order of a few percent, which would be within our given uncertainties. The shielding and thickness correction factors are given in Table 1. Radiocarbon ages referred in this study are calibrated with OxCal 4.2 (https://c14.arch.ox.ac.uk/oxcal.html; Bronk Ramsey 2009) in combination with the INTCAL13 calibration dataset (Reimer et al. 2013).

\section{Results}

In Table 2, the amount of dissolved quartz and ${ }^{9} \mathrm{Be}$ spike; ${ }^{10} \mathrm{Be} /{ }^{9} \mathrm{Be}$ ratios; the relative contribution of the blank correction; the measured ${ }^{10} \mathrm{Be}$ concentrations and the ${ }^{10} \mathrm{Be}$ 
Fig. 5 NW-SE oriented topographic profiles along the western, central and eastern transects. Sample locations and ${ }^{10} \mathrm{Be}$ exposure ages are shown. Green labelled exposure ages represent the first group of boulders, red the second group and blue the third group as discussed in the text. Tentative minimum (blue line) and maximum (blue dashed line) altitudes for the LGM ice also indicated (from Bini et al., 2009)
E

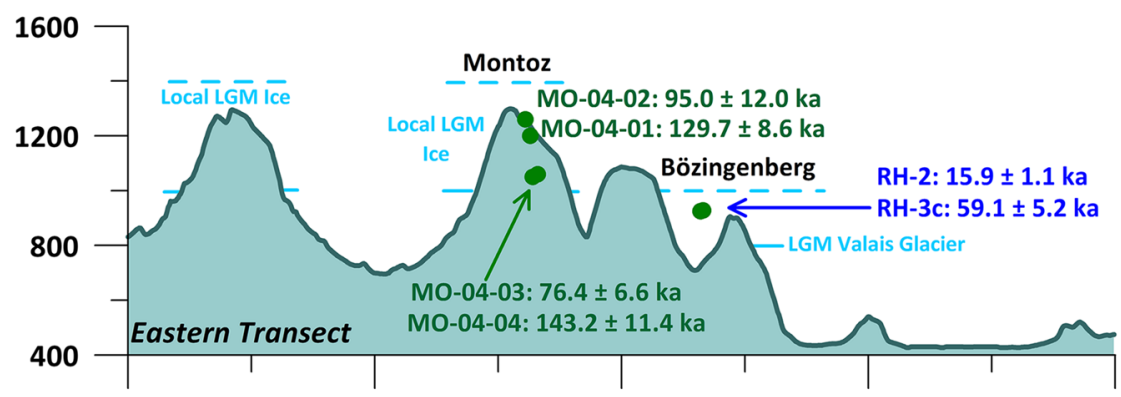

C

D
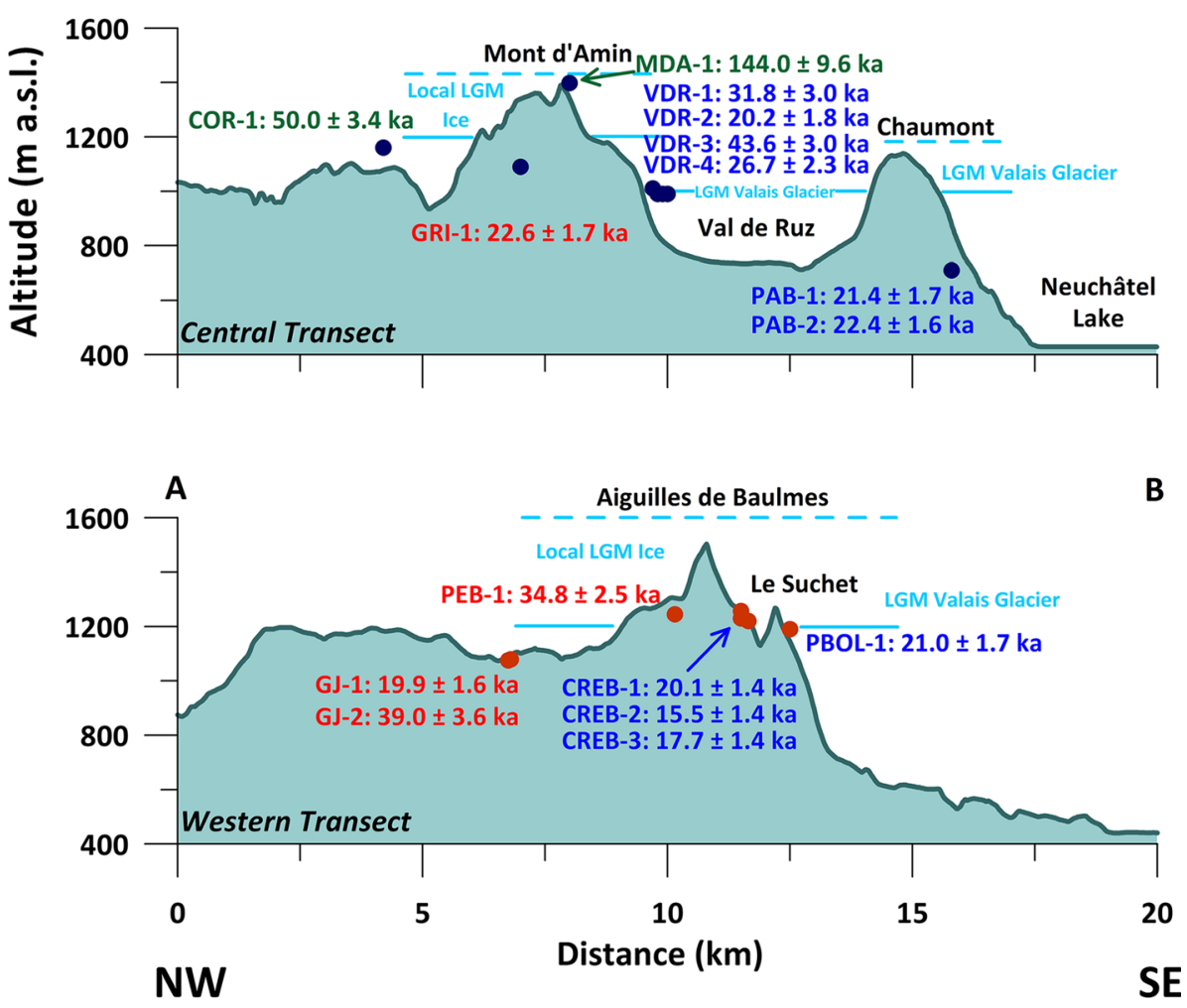

exposure ages (except for boulder bottom sample PAB-3) are given for each sample. The measured ${ }^{10} \mathrm{Be} /{ }^{9} \mathrm{Be}$ ratios range from $(4.24 \pm 0.23) \times 10^{-13}$ to $(42.51 \pm 1.28) \times$ $10^{-13}$. The contribution of the blank correction is between 0.6 and $5.6 \%$. ${ }^{10} \mathrm{Be}$ concentrations vary between $(12.88 \pm 0.66) \times 10^{4} \mathrm{at} / \mathrm{g}$ and $(156.12 \pm 4.71) \times 10^{4} \mathrm{at} /$ g. Erosion-corrected exposure ages with uncertainties including the production rate errors were used for the discussion.

Recalculation of the exposure ages of the boulders from the Montoz in the eastern transect yielded ages between $76.4 \pm 6.6$ and $143.2 \pm 11.4 \mathrm{ka} \quad$ (MO-04-01: $129.7 \pm 8.6 \mathrm{ka}$; MO-04-02: $95.0 \pm 12.0 \mathrm{ka}$; MO-04-03: $76.4 \pm 6.6 \mathrm{ka}$; and MO-04-04: $143.2 \pm 11.4 \mathrm{ka})$. Boulder surfaces RH-2 and RH-3c on the Bötzingerberg are $15.9 \pm 1.1$ and $59.1 \pm 5.2 \mathrm{ka}$ old, respectively (Table 2 ).
The boulder from the lowest altitude is the Pierre-à-Bot in the central transect. The two independent ages $21.4 \pm 1.7 \mathrm{ka} \quad(\mathrm{PAB}-1)$ and $22.4 \pm 1.6 \mathrm{ka} \quad(\mathrm{PAB}-2)$ obtained from this boulder match well within the range of error. The boulder bottom sample PAB-3 yielded a ${ }^{10} \mathrm{Be}$ concentration of $32.99 \pm 1.17$ at $/ g$ (Table 2). The exposure ages from the four Val de Ruz samples are $31.8 \pm 3.0 \mathrm{ka} \quad(\mathrm{VDR}-1), \quad 20.2 \pm 1.8 \mathrm{ka} \quad$ (VDR-2), $43.6 \pm 3.0 \mathrm{ka}(\mathrm{VDR}-3)$ and $26.7 \pm 1.9 \mathrm{ka}$ (VDR-4). The highest erratic boulder in the Jura Mountains on the Mont d'Amin (MDA-1) yielded 144.0 $\pm 9.6 \mathrm{ka}$. The northern most sampled boulder, Le Cornu (COR-1), has been exposed for at least $50.0 \pm 3.4 \mathrm{ka}$ and Le Grison (GRI-1) for at least $22.6 \pm 1.7 \mathrm{ka}$ (Table 2).

There are no old boulders in the western transect. The large Pierre-à-Bolet (PBOL-1) on Le Suchet in the western 
Table $2{ }^{10} \mathrm{Be}$ data of the samples from the Jura Mountains

\begin{tabular}{|c|c|c|c|c|c|c|}
\hline $\begin{array}{l}\text { Sample } \\
\text { name }\end{array}$ & $\begin{array}{l}\text { Quartz dissolved } \\
\text { (g) }\end{array}$ & $\begin{array}{l}{ }^{9} \text { Be spike } \\
(\mathrm{mg})\end{array}$ & $\begin{array}{l}{ }^{10} \mathrm{Be} /{ }^{9} \mathrm{Be} \\
\left(10^{-13}\right)\end{array}$ & $\begin{array}{l}\text { Blank correction } \\
(\%)\end{array}$ & $\begin{array}{l}{ }^{10} \mathrm{Be} \text { concentration } \\
\left(\times 10^{4} \mathrm{at} / \mathrm{g}\right)\end{array}$ & $\begin{array}{l}{ }^{10} \mathrm{Be} \text { exposure age } \\
\text { (ka) }\end{array}$ \\
\hline \multicolumn{7}{|c|}{ Eastern transect } \\
\hline MO-04-01 ${ }^{\mathrm{a}}$ & 38.5364 & 0.4033 & $19.34 \pm 0.58$ & 1.2 & $121.87 \pm 3.70$ & $129.7 \pm 4.7(8.6)$ \\
\hline MO-04-02 ${ }^{\mathrm{a}}$ & 21.7053 & 0.4025 & $8.88 \pm 0.89$ & 2.7 & $97.70 \pm 10.04$ & $95.0 \pm 11.1(12.0)$ \\
\hline MO-04-03 ${ }^{\mathrm{a}}$ & 43.1377 & 0.4034 & $11.82 \pm 0.73$ & 2.0 & $66.04 \pm 4.18$ & $76.4 \pm 5.4(6.6)$ \\
\hline MO-04-04 & 65.6744 & 0.4082 & $29.74 \pm 1.40$ & 0.8 & $111.81 \pm 5.3$ & $143.2 \pm 8.2(11.4)$ \\
\hline $\mathrm{RH}-2$ & 77.5700 & 0.3541 & $4.86 \pm 0.24$ & 4.9 & $12.88 \pm 0.66$ & $15.9 \pm 0.8(1.1)$ \\
\hline $\mathrm{RH}-3 \mathrm{c}$ & 55.5600 & 0.3475 & $12.45 \pm 0.81$ & 1.9 & $46.57 \pm 3.09$ & $59.1 \pm 4.2(5.2)$ \\
\hline \multicolumn{7}{|c|}{ Central transect } \\
\hline PAB-1 & 50.1869 & 0.3041 & $4.24 \pm 0.23$ & 5.6 & $14.78 \pm 0.86$ & $21.4 \pm 1.3(1.7)$ \\
\hline PAB-2 & 50.9088 & 0.3051 & $4.43 \pm 0.22$ & 5.3 & $15.33 \pm 0.81$ & $22.4 \pm 1.2(1.6)$ \\
\hline PAB $-3^{b}$ & 101.8748 & 0.3046 & $18.33 \pm 0.64$ & 1.3 & $32.99 \pm 1.17$ & \\
\hline VDR-1 & 50.1053 & 0.3054 & $7.22 \pm 0.55$ & 3.3 & $25.97 \pm 2.04$ & $31.8 \pm 2.6(3.0)$ \\
\hline VDR-2 & 50.0268 & 0.3041 & $4.75 \pm 0.31$ & 5.0 & $16.72 \pm 1.16$ & $20.2 \pm 1.4(1.8)$ \\
\hline VDR-3 & 49.7426 & 0.3050 & $9.83 \pm 0.43$ & 2.4 & $35.88 \pm 1.62$ & $43.6 \pm 2.1(3.0)$ \\
\hline VDR-4 & 50.6849 & 0.3127 & $6.24 \pm 0.42$ & 3.8 & $22.58 \pm 1.57$ & $26.7 \pm 1.9(2.3)$ \\
\hline MDA-1 & 50.6598 & 0.3069 & $42.51 \pm 1.28$ & 0.6 & $156.12 \pm 4.71$ & $144.0 \pm 5.3(9.6)$ \\
\hline GRI-1 & 50.1271 & 0.3023 & $5.96 \pm 0.32$ & 4.0 & $21.03 \pm 1.18$ & $22.6 \pm 1.3(1.7)$ \\
\hline COR-1 & 46.8240 & 0.3060 & $12.48 \pm 0.51$ & 1.9 & $48.79 \pm 2.04$ & $50.0 \pm 2.3(3.4)$ \\
\hline \multicolumn{7}{|c|}{ Western transect } \\
\hline PBOL-1 & 49.6464 & 0.3083 & $5.77 \pm 0.33$ & 4.1 & $20.96 \pm 1.27$ & $21.0 \pm 1.3(1.7)$ \\
\hline CREB-1 & 47.3671 & 0.3101 & $5.68 \pm 0.28$ & 4.2 & $21.72 \pm 1.11$ & $20.1 \pm 1.1(1.4)$ \\
\hline CREB-2 & 51.9935 & 0.3049 & $4.95 \pm 0.35$ & 4.8 & $16.86 \pm 1.26$ & $15.5 \pm 1.2(1.4)$ \\
\hline CREB-3 & 50.5764 & 0.2892 & $5.88 \pm 0.34$ & 4.0 & $19.67 \pm 1.19$ & $17.7 \pm 1.1$ \\
\hline PEB-1 & 50.8349 & 0.3071 & $10.16 \pm 0.50$ & 2.3 & $36.56 \pm 1.83$ & $34.8 \pm 1.9(2.5)$ \\
\hline GJ-1 & 50.5889 & 0.3061 & $5.45 \pm 0.32$ & 4.3 & $19.22 \pm 1.17$ & $19.9 \pm 1.2(1.6)$ \\
\hline GJ-2 & 41.9368 & 0.3071 & $8.19 \pm 0.59$ & 2.9 & $35.52 \pm 2.63$ & $39.0 \pm 3.1(3.6)$ \\
\hline
\end{tabular}

AMS measurement errors are at $1 \sigma$ level, including the statistical (counting) error and the error due to normalization of standards and blanks. The error weighted average ${ }^{10} \mathrm{Be} /{ }^{9} \mathrm{Be}$ full process blank ratio is $(2.36 \pm 0.10) \times 10^{-14}$. Exposure ages are calculated with the CRONUS-Earth exposure age calculator (http://hess.ess.washington.edu/math/; v. 2.2; Balco et al. 2008 and update from v. 2.1 to v. 2.2 published by Balco in October Balco et al. 2009) and time dependent Lal (1991)/Stone (2000) scaling model using the NE North American production rate calibration dataset (Balco et al. 2009). Exposure ages are corrected for dip of rock surface, shielding of surrounding topography, and sample thickness, as explained in the text; the uncertainties reported in parentheses also include the production rate error. $2.65 \mathrm{~g} / \mathrm{cm}^{3}$ for rock density and a half-live of $1.39 \mathrm{Ma}$ for ${ }^{10} \mathrm{Be}$ (Korschinek et al. 2010; Chmeleff et al. 2010) are used for the age calculations

${ }^{a}$ Reported concentrations are from Graf et al. (2007) and exposure ages are recalculated

b Sample from the bottom of the boulder

transect was exposure-dated to $21.0 \pm 1.7 \mathrm{ka}$. Morphologically higher samples from the Crébillons yielded ${ }^{10} \mathrm{Be}$ ages of $20.1 \pm 1.4 \mathrm{ka}$ (CREB-1), $15.5 \pm 1.4 \mathrm{ka}$ (CREB2 ), and $17.7 \pm 1.4 \mathrm{ka}(\mathrm{CREB}-3)$. The samples to the north of $\mathrm{Col}$ des Aiguillons- $\mathrm{Col}$ des Etroits have exposure ages of $34.8 \pm 2.5 \mathrm{ka}$ for PEB-1, $19.9 \pm 1.6 \mathrm{ka}$ for GJ-1 and $39.0 \pm 3.6$ for GJ-2 (Table 2).

\section{Interpretation of exposure ages}

In the following discussion, we have divided the erratic boulders that were sampled along the three transects into three groups based on their geographical positions (Fig. 4) and elevation as displayed in the three profiles (Fig. 5). The three groups are: (1) boulders that were affected by neither Jurrasian nor Valais ice during the LGM; (2) boulders that were affected by local Jurrasian LGM ice; and (3) boulders that were deposited during the LGM by the Valais Glacier. The first group is made up of boulders that are located beyond the LGM extent of both the Valais Glacier and the local glaciers in the Jura Mountains. These are namely the Montoz boulders (MO-04-01 to 04), Mont d'Amin (MDA1) and Le Cornu (COR-1). Erratic boulders Le Grison (GRI-1), Pierre d'en Bas (PEB-1) and two near GrangesJaccard (GJ-1 and GJ-2) constitute the second group. These boulders are situated beyond the extent of the LGM Valais 
Glacier, however they may have been reworked (displaced and re-deposited) by the local Jurrasian ice during the LGM. The third group is made up of boulders clearly deposited by the LGM Valais Glacier. These are the boulders from Bözingenberg (RH-2 and 3c), Neuchâtel (PAB-1), Montagne de Chézard (VDR-1 to 4), Le Suchet (PBOL-1) and the Crébillons Alpine farmhouse (CREB-1 to 3$)$.

Numerous ages from the first group of Alpine boulders found beyond the LGM extent of ice indicate that these were deposited prior to the LGM. Alpine glaciers advanced into the Jura Mountains at least one time prior to the LGM. Exposure ages from these erratic boulders vary from $50.0 \pm 3.4$ to $144.0 \pm 9.6 \mathrm{ka}$ (Fig. 4). As the geomorphological constraints of this advance or these advances were not preserved, the broad distribution of the exposure ages may be explained with several scenarios. Therefore we provide two end-member scenarios. In the first endmember scenario, one can assume that Alpine ice overrode the Jura Mountains after ca. 71 ka during MIS-4 (Lisiecki and Raymo 2005). The older boulders (>100 ka) should then contain inherited concentrations and younger ones have not experienced any post-depositional processes that would produce younger ages (e.g., Akçar et al. 2011). However, exposure ages from two boulders from Montoz match well with that of Mont d'Amin (Fig. 4). In addition, inheritance in boulders deposited by glaciers is uncommon, i.e. either absent or gauged within the uncertainties (Putkonen and Swanson 2003; Putkonen and O'Neal 2006; Abbühl et al. 2009; Heyman et al. 2011), therefore we conclude that this scenario is not plausible. In the second end-member scenario, we assume that the Valais Glacier expanded onto the Jura Mountains prior to ca. $150 \mathrm{ka}$ (MIS-6 or earlier; Lisiecki and Raymo 2005) and deposited boulders of the first group. In that case, younger exposure ages are caused by the exhumation of the boulders and the older boulders do not contain inherited ${ }^{10} \mathrm{Be}$ concentrations and did not experience any process after deposition. The second scenario seems plausible at first sight, however, the position of the old erratic boulders on the summit of Montoz and mainly Mont d'Amin poses a severe conceptual problem with respect to the existence of local glaciers, at least in the eastern and central part of the Jura Mountains. Therefore the most likely scenario lies somewhere between our two endmembers. Jurrasian glaciers likely mobilized previously deposited Alpine erratic boulders (Aubert 1965) and re-deposited them in the ablation zones. Keeping this line of evidence in mind, we suggest that these boulders were brought to the Jura Mountains prior to MIS-6, during MIS-8 or even earlier (cf. Preusser et al. 2011). Several of the boulders were subsequently may have been re-transported and re-deposited by local glaciers during MIS-6. The ages from the first group suggest that these boulders, which lie outside of the LGM extent of both local glaciers and the Valais Glacier, were brought from the Alpine valleys and deposited by glaciers in the Jura Mountains sometime before $150 \mathrm{ka}$.

The second group comprises erratic boulders Le Grison (GRI-1), Pierre d'en Bas (PEB-1) and two near GrangesJaccard (GJ-1 and GJ-2). Based on the ${ }^{10}$ Be exposure ages and the boulder positions, we conclude that the second group of boulders were deposited during the same advance or advances as the boulders of the first group but were relocated during the LGM by local Jurrasian ice during the LGM (Figs. 4, 5). Even if the area beyond the Col des Aiguillons and Col des Etroits was free of Alpine ice during the LGM, the plateaus in the western part of the Jura Mountains are reported to have been covered by local ice (Aubert 1965; Buoncristiani and Campy 2004b). Strictly, we cannot rule out that the boulder positions were changed through periglacial processes, this ice seems to have moved boulders; particularly the remote boulders from the western transect (PEB-1, GJ-1 and GJ-2). In the western part of the grassland, north of Cole des Etroits, where GJ-1 and GJ-2 were sampled, it is boggy and marked as local till on the geological map (Rigassi and Jaccard 1995). This also suggests that these boulders, carried by a pre-LGM Valais Glacier, may have been remobilised by a local ice-cap during the last glaciation. As these quartzite boulders are unsuitable for construction material, we exclude any human activity on them. The position of GRI-1 $(22.6 \pm 1.7 \mathrm{ka})$ allows that it was actually deposited by Alpine ice during the LGM. It is possible that Alpine ice flowed into the Val de la Sagne probably from Val de Travers over the $1000 \mathrm{~m}$-high swell north of Noirague, and thus extended slightly more to the north than interpreted from the geologic map (Rigassi and Jaccard 1995).

The Valais Glacier deposited the third group of boulders during the LGM (RH-2, RH-3c, PAB-1, PBOL-1, VDR-1 to 4 , and CREB-1 to 3). Every one of these boulders lies clearly within the morphologically-defined extent of the LGM Valais Glacier (Bini et al. 2009). The LGM Valais Glacier reached its maximum altitude of ca. $1250 \mathrm{~m}$ on its left lateral side at around $20.1 \pm 1.4 \mathrm{ka}$ (CREB-1) (Figs. 4, 5). This is also supported by the exposure age of Pierre-àBôt (PAB-1: $21.4 \pm 1.7 \mathrm{ka}$ ). Successive exhumation may explain both the internal age distribution of the samples and the relative age difference with other boulders of the last glaciation (CREB-2: $15.5 \pm 1.4 \mathrm{ka}$ and CREB-3: $17.7 \pm 1.4 \mathrm{ka}$ ) (cf. Akçar et al. 2011). Within the central transect (third group boulders), the valley floor of Val de Ruz and the eastern part of Montagne de Chézard are covered by basal till of the LGM advance (Bourquin et al. 1946). In agreement with this field evidence, four of the six ages range between $26.7 \pm 2.3$ and $20.2 \pm 1.8 \mathrm{ka}$ (VDR2, VDR-4, PAB-1, PAB-2) (Table 2), clear LGM ages. In 
contrast, the two older ages suggest that earlier deposited boulders were repositioned during the LGM (VDR-3: $43.6 \pm 3.0 \mathrm{ka}$ and VDR-1: $31.8 \pm 3.0 \mathrm{ka}$ ), as suggested above for group two boulders. The ${ }^{10} \mathrm{Be}$ concentration from PAB-3 is $>2$ times more than boulder top samples PAB-1 and PAB-2. We interpret this to show that the boulder was exposed previously with what is now the bottom surface facing upwards. Subsequently it was transported to its present position and it was overturned so that a previously unexposed surface was then newly exposed. At Bözingenberg (eastern transect, group three) the sampled boulders provide ages of $15.9 \pm 1.1 \mathrm{ka}(\mathrm{RH}-$ 2) and $59.1 \pm 5.2 \mathrm{ka}(\mathrm{RH}-3 \mathrm{c})$. The boulders lie within the well-constrained LGM morphology, therefore we interpret the older age to reflect re-positioning of a previously deposited boulder. The age of RH-2 likely stems from exhumation of the boulder.

\section{Implications for glacier advances onto the Jura Mountains}

To reach the Montoz area (Figs. 4, 5), the pre-LGM Valais Glacier had to penetrate the Schüss gorge (TaubenlochSchlucht) north of Bienne. Along this gorge, Welten (1972) analysed the pollen content of samples from two cores close to Frinvillier and from one close to Reuchenette. The base of the three cores shows pollen deposition in a cold lacustrine environment, while the upper part indicates an interglacial (Eemian) period. As there is no natural dam explaining the deposition of these $30 \mathrm{~m}$-thick overconsolidated lacustrine sediments in the Schüss gorge, Welten claimed that the lower part of the sequence was due to the presence of an advancing glacier. He goes on to suggest that the high content of interglacial pollen in the upper part of the cores stemmed from subsequent erosion of the bare soil. Afterwards, the Valais Glacier overrode the sediments. This adds a problem to the timing of the LGM, because in Welten's scenario, it occurred just after the Eemian. If Welten's interpretation is plausible, the smaller boulders on Montoz, whose younger ages were attributed to post-depositional coverage and re-working, may be related to such an early advance. But it is difficult to explain how this ice reached the top of the Montoz without affecting the boulders on its southern flank, therefore it seems unlikely. As an alternative, a retreating glacier may have temporarily dammed the Schüss gorges, and sedimentation might have begun under cold climate conditions before full interglacial conditions were achieved. The overconsolidation might have occurred during MIS-2, and this implies that the LGM Valais Glacier invaded this gorge. This is a conceptual difference that shows the need for further study of the pollen profiles north of Bienne.
One of the key sections in the Swiss Midlands is the pollen record of Meikirch, $10 \mathrm{~km}$ north of Bern (Fig. 4). The ca. $70 \mathrm{~m}$-long monotonic lacustrine sediment core has been attributed to the Eemian and Holsteinian interglacials (Welten 1982, 1988; Schlüchter 1989), which suggests that this area was not glaciated during MIS-6. As a direct consequence, the existence of the "Rissian" glacier advance reaching the high Jura Mountains and far into France was open to debate. Meanwhile, other studies show that the terrestrial system seems to have reacted to most of the climatic changes registered in the continuous archives of polar ice and deep-sea sediments. In particular, the cool environment conditions of the early late Pleistocene were dated (Welten 1982; Wegmüller 1992; 1996) and correlated with the first two cooling events (MIS-5d and 5b) of the last glacial cycle (Preusser 2004; Preusser et al. 2003). A further cold event is registered during MIS-4 (Preusser et al. 2003; Preusser and Degering 2007). The Meikirch key section was dated and re-interpreted by Preusser et al. (2005) (Fig. 1). The monotone lacustrine sequence was dated to MIS-7, the till below to MIS-8, and the sediment complex above was tentatively correlated to MIS-6 and MIS-2 (LGM). Beside the Meikrich record, two long Pleistocene sediment records were recently dated in the confluence area of the Valais and Aare glaciers. The most complete record from the Swiss Midlands is still the Thalgut gravel pit (15 km SE of Bern), where at least four different glacial advances and two interglacials are documented by pollen analysis. The Kirchdorf delta gravels, concordantly underlying the Eemian Thalgut lacustrine clays (OSL ages of $125 \pm 12$ and $138 \pm 14 \mathrm{ka}$ ), are correlated with MIS-6 (Welten 1988; Preusser et al. 2005). Two additional glacier advances are recorded below the Kirchdorf delta gravels, and the whole sequence is topped by gravels and till of the LGM. In the Mattstetten gravel pit (9 km NE of Bern) a succession of deformed sands and gravels is dated by OSL to MIS-5d (Preusser 2004). Summarising these profiles, there is evidence for glacier presence in the Swiss Midlands during MIS-8 at Meikirch, as well as unmistakable evidence of glaciers during MIS-6 stage in Mattstetten and very likely in Meikirch, while in the Thalgut pit, only the upper gravels of the glacial succession were preserved. Another line of evidence for the glaciations of the Swiss Alpine Foreland was recently provided by Dehnert et al. (2010). They applied U/Th, OSL and burial dating techniques to proglacial deltaic sediments of the Höhenschotter in Landiswil, which is situated beyond the LGM extent. Burial dating with cosmogenic ${ }^{10} \mathrm{Be}$ and ${ }^{26} \mathrm{Al}$ indicated a lower dating limit of around $400 \mathrm{ka}$ for this study. Based on U/Th and OSL results, timing of deposition of this sequence was then correlated to MIS-6.

The presence of glaciers in the Swiss Alpine Foreland during MIS-8 and their absence during MIS-6 (sensu 
Schlüchter 1989) support our suggestion about the first delivery of the Alpine erratic boulders onto the Jura Mountains. During the MIS-8 or even earlier, advancing Alpine glaciers should have reached and overflowed the Jura Mountains. This advance might actually be correlated to the Möhlin Glaciation, which is attributed to the most extensive glaciation of the Northern Alpine Foreland during the MIS-10 (Keller and Krayss 2010). Although the sediment records of this glaciation seem to be rare, the first overdeepening and widening of the Alpine valley systems were attributed to this glaciation (Preusser et al. 2011 and references therein).

Marine and polar isotope records suggest periods of cold climate conditions around 122-106 ka (MIS-5d) and around 71-57 ka MIS-4 (Lisiecki and Raymo 2005). In the Swiss Midlands, terrestrial records provide growing evidence of climatic deterioration during these time intervals. The Galgenmoos pollen profile near Huttwil shows severe climate deterioration with steppe conditions during MIS-5d and MIS-5b (Wegmüller et al. 1992). The delta gravel below the Gossau interstadial complex was correlated with MIS-5d (Preusser et al. 2003). Identification of the corresponding glacigenic sediments in the proximity of Lake Geneva, where the Valais Glacier flowed out of its valley, is therefore highly relevant. In fact, Arn (1984) recognized at least two restricted glacial advances after the Eemian and before the LGM. Based on available dating methods, they were attributed to the middle Würmian. The Cossoney stage occurred $>366^{\prime} 000{ }^{14} \mathrm{C}$ yr BP (the age obtained from the overlying Sernaclens interstadial). An interesting sediment succession has been observed in the Veveyse valley, where three basal tills were differentiated. The middle one reached up to only $800 \mathrm{~m}$ asl, and buried lacustrine sediments with wood fragments $>366^{\prime} 000{ }^{14} \mathrm{C}$ yr BP. It is not clear if this restricted glaciation corresponds to the Cossoney stage or the subsequent Bioley-Orjulaz stage. The latter occurred before the Bettens interstadial dated to $25^{\prime} 090 \pm 550{ }^{14} \mathrm{C}$ yr BP $\left(30^{\prime} 595-28^{\prime} 119\right.$ cal BP; Arn 1985). Moreover, this younger glacial advance did not leave the Lake Geneva area. At the base of the BioleyOrjulaz fluvioglacial gravels, a mammoth tusk is dated to $34 / 6000_{-1800}^{+2700}{ }^{14} \mathrm{C}$ yr BP (Weidmann 1974). This time interval is recognised as interstadial from peat deposits in Gossau and in Niederweningen. The peat-rich Gossau interstadial complex (Welten 1982) was formed during MIS-3 from ca. $54^{\prime} 000 \pm 3^{\prime} 000$ and $33^{\prime} 000 \pm 2^{\prime} 500{ }^{14} \mathrm{C}$ kyr BP $\left(67^{\prime} 218-29^{\prime} 247\right.$ cal BP and $45^{\prime} 320-33^{\prime} 035$ cal BP, respectively; Schlüchter et al. 1987). Fossil beetles indicate that the temperatures during this interstadial were lower than today and lower than MIS-5c and 5a (Jost-Stauffer et al. 2005). The Gossau interstadial complex itself is covered by gravels showing a periglacial overprint. A thinner layer of peat above this gravel was dated to $28^{\prime} 470 \pm 230{ }^{14} \mathrm{C}$ yr BP $\left(33^{\prime} 163-31^{\prime} 644\right.$ cal BP; combination of three ${ }^{14} \mathrm{C}$ ages from Schlüchter et al. 1987). Thus the proximity of the Valais Glacier recorded in the Lausanne area between $34 / 600_{-1 / 800}^{+2,700}{ }^{14} \mathrm{C}$ yr and $25^{\prime} 090 \pm 550$ ${ }^{14} \mathrm{C}$ yr BP may correlate with the severe climate deterioration recorded in the Zürich area between ca. $33^{\prime} 000 \pm 2^{\prime} 500$ and $28^{\prime} 470 \pm 230{ }^{14} \mathrm{C}$ yr BP.

Between Lake Geneva and Lake Neuchâtel, outcrops often show a single glacial sequence of prograding fluvioglacial gravels and overlaying basal till. Two exceptions have been reported so far. First is that the combination of the profiles from Grandson and Les Tuileris suggests an additional glacier advance before the LGM (Arn 1984). The second is from the Finsterhennen gravel pit to the south of Lake Bienne. Fluvioglacial gravels dated to ca. $70 \mathrm{ka}$ (Preusser and Degering 2007) are overlaid by a relict till with large Vallaisian erratic boulders. In most of the gravel pit, this layer is reduced to a boulder lag. It is suggested that the deposition of the lower till may have occurred during MIS-4, followed by a period of weathering during MIS-3. The deposition of the upper gravel where a mammoth tusk was found occurred at $25^{\prime} 370 \pm 190{ }^{14} \mathrm{C}$ yr BP (30'062-28'931 cal BP; Schlüchter 2004).

Piedmont glaciers extended beyond the Alpine valleys and reached the Foreland during the LGM. From data obtained in the Swiss Alps and from the Eastern Alps, it is well established that glaciers started to build up in the inner-Alpine area sometime after $30 \mathrm{ka}$, and reached their maximum extent between 24 and $21 \mathrm{ka}$ (Schlüchter and Röthlisberger 1995; Keller and Krayss 2000). Ice decay began around $24 \mathrm{ka}$ (recalculated from Ivy-Ochs et al. 2004; Reber et al. 2014). Terminus of the Valais Glacier was still in the Foreland, near Neuchâtel at ca. $22 \mathrm{ka}$. Then it retreated to a position around Le Suchet. The final demise of the Valais Glacier still needs to be explored in detail. Meanwhile, the Arve glacier extended close to Lyon around $25 \mathrm{ka}$. Two ${ }^{10} \mathrm{Be}$ ages of $26.4 \pm 1.8$ and $27.6 \pm 2.8 \mathrm{ka}$ from Les Arpilles suggest that the maximum extent of the Valais Glacier was reached at the end of MIS-3 (Coutterand and Buoncristiani 2006). Although these authors did not document their laboratory data and age calculations, it is possible that these ages correspond to estimated minimal, snow-corrected ages of about $24 \mathrm{ka}$. As mentioned in the introduction, the Valais Glacier did not originate in the Rhône ice dome and the Aletsch ice field, but in the southern tributary valleys of the Valasian Alps and the Mont Blanc Massif. Although, during the LGM, the circulation pattern may have shifted southwards (Florineth and Schlüchter 1998) and favoured snow accumulation in the Southern Alps, the current discussion seems to focus on a dating problem rather than on an 
important west-east time lag in response to climatic forcing.

\section{Conclusions}

In this study, we addressed an old question: when were the advances of Alpine glaciers onto the Jura Mountains? The last advance of the Valais Glacier took place during the LGM. Geomorphological features and glacial and glaciofluvial deposits (e.g., Alpine erratic boulders) related to this advance are well defined. Our exposure dates from boulders along the left lateral side of the LGM Valais Glacier give an average of $21.9 \pm 1.8 \mathrm{ka}$. In contrast, the evidence of older Alpine glaciations, which reached beyond the LGM extent, is actually defined by very few Alpine boulders and relict till deposits in the Jura Mountains which are located at higher elevation and to the west of the LGM Valais Glacier. Pre-LGM advances of Alpine glaciers are morphologically, as well as chronologically, poorly constrained. To understand the timing, we identified Alpine erratic boulders within and beyond the LGM extent of the Valais Glacier along three transects and sampled these for surface exposure dating with ${ }^{10} \mathrm{Be}$. The oldest advance, which may be attributed to a MIS-8 or an earlier glaciation (cf. Preusser et al. 2011), transported erratic boulders from the Alps and deposited them in the Jura Mountains. We consider this event to have been before our oldest exposure age, $144.0 \pm 9.6 \mathrm{ka}$ (MDA-1). During the LGM, local Jurrasian glaciers might have reworked the boulders beyond the extent of the LGM Valais Glacier, as well as the Valais Glacier that displaced and re-deposited previously transported erratic boulders in addition to the fresh ones. Boulders in the Jura Mountains that lie beyond the LGM extent of the Valais Glacier were deposited prior to $144.0 \pm 9.6 \mathrm{ka}$. The question of the age of the most extensive glaciation on the Swiss forelands remains unanswered.

Acknowledgments We would like to thank Gilles Borel and M. Weidmann for their support in securing the sampling permission issued by the Canton de Vaud. We also thank the Zurich AMS Facility operated by the Swiss Federal Institute of Technology, Zurich, Switzerland. The quality of the paper has benefited from constructive reviews of Hanns Kerschner and the anonymous reviewer, which are especially acknowledged. The Swiss National Science Foundation (grant number 200020-105220/1) funded the research on which this article is based, and we are grateful for its support.

\section{References}

Abbühl, M. L., Akçar, N., Strasky, S., Graf, A., Ivy-Ochs, S., \& Schlüchter, C. (2009). A zero-exposure time experiment on an erratic boulder: evaluating the problem of pre-exposure in
Surface Exposure Dating. Quaternary Science Journal (Eiszeitalter und Gegenwart), 58, 1-11.

Akçar, N. (2006). Paleoglacial Records from the Black Sea Area of Turkey: Field and dating evidence. Ph.D. dissertation, University of Bern, Bern, Switzerland, $187 \mathrm{pp}$.

Akçar, N., Ivy-Ochs, S., Kubik, P. W., \& Schlüchter, C. (2011). Postdepositional impacts on 'Findlinge' (erratic boulders) and their implications for surface exposure dating. Swiss Journal of Geosciences, 104, 445-453.

André, M.-F. (2002). Rates of postglacial rock weathering on glacially scoured outcrops (Abisko-Riksgransen area, 68 degrees N). Geografiska Annaler, 84A, 139-150.

Antenen, M., Kellerhals, P., \& Tröhler, B. (2004). Geologischer Atlas der Schweiz, 1:25'000 Blatt 109 "Büren a. A”. Wabern, Schweiz: Bundesamt für Wasser und Geologie.

Arn, R. (1984). Les formations quaternaires de l'Orbe et du Nozon, au pied du Jura. Bulletin de Géologie Lausanne, 275, 17-42.

Arn, R. (1985). Les sédiments interstadiaires wurmiens de Senarclens (VD). Bulletin de la Société Vaudoise des Sciences Naturelles, 77, 223-239.

Aubert, D. (1965). Calotte glaciaire et morphologie jurassiennes. Eclogae Geologicae Helvetiae, 58, 555-578.

Balco, G., Briner, J., Finkel, R. C., Rayburn, J. A., Ridge, J. C., \& Schaefer, J. M. (2009). Regional beryllium-10 production rate calibration for late-glacial northeastern North America. Quaternary Geochronology, 4, 93-107.

Balco, G., Stone, J. O., Lifton, N. A., \& Dunai, T. J. (2008). A complete and easily accessible means of calculating surface exposure ages or erosion rates from $\mathrm{Be}-10$ and $\mathrm{Al}-26$ measurements. Quaternary Geochronology, 3, 174-195.

Bini, A., Buonchristiani, J.-F., Couterand, S., Ellwanger, D., Felber, M., Florineth, D., Graf, H.R., Keller, O., Kelly, M., Schlüchter, C. \& Schöneich, P. (2009). Die Schweiz während des letzteiszeitlichen Maximums (LGM), 1:500 000. Bundesamt für Landestopographie, swisstopo. Wabern, Switzerland.

Bourquin, P., Suter, H., \& Fallot, P. (1946). Atlas Geologique de la Suisse, 1:25'000 Feuilles 114 "Biaufond", 115 "Les Bois", 116 "La Ferrière", 117 "St Imier" et Notices Explicatives. Berne: Service hydrologique et géologique national.

Bronk Ramsey, C. (2009). Bayesian analysis of radiocarbon dates. Radiocarbon, 51(1), 337-360.

Buoncristiani, J. F. \& Campy, M. (2004a). The paleogeography of the last two glacial episodes in France: the Alps and Jura. In Ehlers, J. and Gibbard, P.L. (Eds.), Quaternary Glaciations-Extent and Chronology. Part I: Europe (101-110). Amsterdam: Elsevier.

Buoncristiani, J. F., \& Campy, M. (2004b). Expansion and retreat of the Jura ice sheet (France) during the last glacial maximum. Sedimentary Geology, 165, 253-264.

Chmeleff, J., von Blanckenburg, F., Kossert, K., \& Jakob, D. (2010). Determination of the Be-10 half-life by multicollector ICP-MS and liquid scintillation counting. Nuclear Instruments \& Methods in Physics Research Section B-Beam Interactions with Materials and Atoms, 268, 192-199.

Coutterand, S., \& Buoncristiani, J.-F. (2006). Paléogéograhie du dernier maximum glaciaire du pléistocène récent de la région du Massif du Mont Blanc, France. Quaternaire, 17, 35-43.

Dehnert, A., Preusser, F., Kramers, J. D., Akçar, N., Kubik, P. W., Reber, R., \& Schlüchter, C. (2010). A multi-dating approach applied to proglacial sediments attributed to the Most Extensive Glaciation of the Swiss Alps. Boreas, 39, 620-632.

Dunne, J., Elmore, D., \& Muzikar, P. (1999). Scaling factors for the rates of production of cosmogenic nuclides for geometric shielding and attenuation at depth on sloped surfaces. Geomorphology, 27, 3-11.

Florineth, D., \& Schlüchter, C. (1998). Reconstructing the Last Glacial Maximum (LGM) ice surface geometry and flowlines in 
the Central Swiss Alps. Eclogae Geologicae Helvetiae, 91, 391-407.

Gosse, J. C., \& Phillips, F. M. (2001). Terrestrial in situ cosmogenic nuclides: theory and application. Quaternary Science Reviews, $20,1475-1560$.

Graf, A. A. (2008). Surface exposure Dating on LGM and pre-LGM erratic boulders - a comparison of paleoclimate records from both hemispheres. Ph.D. dissertation, University of Bern, Bern, Switzerland, $215 \mathrm{pp}$.

Graf, A. A., Strasky, S., Ivy-Ochs, S., Akçar, N., Kubik, P. W., Burkhard, M., \& Schlüchter, C. (2007). First results of cosmogenic dated pre-last glaciation erratics from the Montoz area, Jura Mountains, Switzerland. Quaternary International, 164-165, 43-52.

Hantke, R. (1978). Eiszeitalter, Band I: Die jüngste Erdgeschichte der Schweiz und ihrer Nachbargebiete (468 pp.). Thun, Schweiz: Ott Verlag AG.

Heyman, J., Stroeven, A. P., Harbor, J. M., \& Caffee, M. W. (2011). Too young or too old: evaluating cosmogenic exposure dating based on an analysis of compiled boulder exposure ages. Earth and Planetary Science Letters, 302, 71-80.

Ivy-Ochs, S., Kerschner, H., Reuther, A., Maisch, M., Sailer, R., Schaefer, J., Kubik, P.W., Synal, H. \& Schlüchter, C. (2006). The timing of glacier advances in the northern European Alps based on surface exposure dating with cosmogenic 10Be, 26Al, $36 \mathrm{Cl}$, and $21 \mathrm{Ne}$. In Siame, L.L., Bourlès, and D.L., Brown, E.T. (Eds.), Application of cosmogenic nuclides to the study of Earth surface processes: The practice and the potential (43-60). Boulder: Geological Society of America.

Ivy-Ochs, S., Schafer, J., Kubik, P. W., Synal, H. A., \& Schlüchter, C. (2004). Timing of deglaciation on the northern Alpine Foreland (Switzerland). Eclogae Geologicae Helvetiae, 97, 47-55.

Jost-Stauffer, M., Coope, G. R., \& Schlüchter, C. (2005). Environmental and climatic reconstructions during Marine Oxygen Isotope Stage 3 from Gossau, Swiss Midlands, based on coleopteran assemblages. Boreas, 34, 53-60.

Keller, O., \& Krayss, E. (2000). Die Hydrographie des Bodenseeraums in Vergangenheit und Gegenwart (Erläuterungen zur Karte " Vorlandvereisung des Bodensee-Rheingletschers in der Würmeiszeit"). Berichte der St. Gallischen Naturwissenschaftlichen Gesellschafft, 89, 39-56.

Keller, O., \& Krayss, E. (2010). Mittel- und spätpleistozäne Stratigraphie und Morphogenese in Schlüsselregionen der Nordschweiz. Quaternary Science Journal, 59, 88-119.

Kelly, M. A., Buoncristiani, J.-F., \& Schlüchter, C. (2004). A reconstruction of the last glacial maximum (LGM) ice-surface geometry in the western Swiss Alps and contiguous Alpine regions in Italy and France. Eclogae Geologicae Helvetiae, 97, 57-75.

Kohl, C. P., \& Nishiizumi, K. (1992). Chemical isolation of quartz for measurement of in situ produced cosmogenic nuclides. Geochimica Cosmochimica Acta, 56, 3583-3587.

Korschinek, G., Bergmaier, A., Faestermann, T., Gerstmann, U. C., Knie, K., Rugel, G., et al. (2010). A new value for the half-life of Be-10 by Heavy-Ion Elastic Recoil Detection and liquid scintillation counting. Nuclear Instruments \& Methods in Physics Research Section B-Beam Interactions with Materials and Atoms, 268, 187-191.

Kubik, P. W., \& Christl, M. (2010). 10Be and 26Al measurements at the Zurich $6 \mathrm{MV}$ Tandem AMS facility. Nuclear Instruments and Methods in Physics Research B, 268, 880-883.

Lal, D. (1991). Cosmic-Ray Labeling of Erosion Surfaces-Insitu Nuclide Production-Rates and Erosion Models. Earth and Planetary Science Letters, 104, 424-439.

Lisiecki, L.E. \& Raymo, M.E. (2005). A Pliocene-Pleistocene stack of 57 globally distributed benthic delta O-18 records. Paleoceanography, 20 (2005). doi:10.1029/2005pa001164.
Nussbaum, F., \& Gygax, F. (1935). Zur Ausdehnung des risseiszeitlichen Rhonegletschers im französischen Jura. Eclogae Geologicae Helvetiae, 28, 659-665.

Penck, A. \& Brückner, E. (1909). Die Alpen im Eiszeitalter (364 pp.). Leipzig: H. Tauchnitz.

Pfiffner, O.A. (2009). Geologie der Alpen (359 pp.). Bern: Haupt.

Preusser, F. (2004). Towards a chronology of the Late Pleistocene in the northern Alpine Foreland. Boreas, 33, 195-210.

Preusser, F., Blei, A., Graf, H. R., \& Schlüchter, C. (2007). Luminescence dating of Würmian (Weichselian) proglacial sediments from Switzerland: methodological aspects and stratigraphical conclusions. Boreas, 36, 130-142.

Preusser, F., \& Degering, D. (2007). Luminescence dating of the Niederweningen mammoth site, Switzerland. Quaternary International, 164-65, 106-112.

Preusser, F., Drescher-Schneider, R., Fiebig, M., \& Schlüchter, C. (2005). Reinterpretation of the Meikirch pollen record, Swiss Alpine Foreland, and implications for Middle Pleistocene chronostratigraphy. Journal of Quaternary Science, 20, 607-620.

Preusser, F., Geyh, M. A., \& Schlüchter, C. (2003). Timing of late pleistocene climate change in lowland Switzerland. Quaternary Science Reviews, 22, 1435-1445.

Preusser, F., Graf, H. R., Keller, O., Krayss, E., \& Schlüchter, C. (2011). Quaternary glaciation history of northern Switzerland. Quaternary Science Journal, 60, 282-305.

Putkonen, J., \& O'Neal, M. (2006). Degradation of unconsolidated Quaternary landforms in the western North America. Geomorphology, 75, 408-419.

Putkonen, J., \& Swanson, T. (2003). Accuracy of cosmogenic ages for moraines. Quaternary Research, 59, 255-261.

Reber, R., Akçar, N., Ivy-Ochs, S., Tikhomirov, D., Burkhalter, R., Zahno, C., et al. (2014). Timing of retreat of the Reuss Glacier (Switzerland) at the end of the Last Glacial Maximum. Swiss Journal of Geosciences, 107, 293-307.

Reimer, P. J., Bard, E., Bayliss, A., Beck, J. W., Blackwell, P. G., Bronk Ramsey, C., et al. (2013). IntCal13 and Marine13 Radiocarbon Age Calibration Curves 0-50,000 Years cal BP. Radiocarbon, 55(4), 1869-1887.

Rigassi, D., \& Jaccard, M. (1995). Geologischer Atlas der Schweiz, 1:25'000. Wabern: Swisstopo.

Schlüchter, C. (1989). Thalgut: ein umfassendes eiszeitstratigraphisches Referenzprofil im nördlichen Alpenvorland. Eclogae Geologicae Helvetiae, 82, 277-284.

Schlüchter, C. (2004). The Swiss glacial record-a schematic summary. In Ehlers, J. and Gibbard, P.L. (Eds.), Quaternary Glaciations-Extent and Chronology. Part I: Europe (413-418). Amsterdam: Elsevier.

Schlüchter, C., Maisch, M., Suter, J., Fitze, P., Keller, W. A., Burga, C. A., \& Wynistorf, E. (1987). Das Schieferkohlen-Profil von Gossau (Kanton Zürich) und seine eiszeitstratigraphische Stellung innerhalb der letzten Eiszeit. Vierteljahrsschrift der Naturforschenden Gesellschaft in Zürich, 132, 135-174.

Schlüchter, C., \& Röthlisberger, C. (1995). 100000 Jahre Gletschergeschichte (pp. 47-63). Sonderdruck aus Gletscher im ständigen Wandel: Hochschulverlag AG an der ETH Zürich.

Shakun, J. D., \& Carlson, A. E. (2010). A global perspective on Last Glacial Maximum to Holocene climate change. Quaternary Science Reviews, 29, 1801-1816.

Stone, J. O. (2000). Air pressure and cosmogenic isotope production. Journal of Geophysical Research, 105(B10), 23753-23759.

Synal, H.-A., Bonani, G., Dobeli, M., Ender, R. M., Gartenmann, P., Kubik, P. W., et al. (1997). Status report of the PSI/ETH AMS facility. Nuclear Instruments and Methods in Physics Research B, 123, 62-68.

Wegmüller, S. (1992). Vegetationsgeschichtliche und stratigraphische Untersuchungen an Schieferkohlen des nördlichen 
Alpenvorlandes. Denkschreiben der Schweizerischen Akademie der Naturwissenschaften, 102, 1-82.

Wegmüller, S. (1996). Palynostratigraphic studies on lignite of the "Zeller gravels" situated north of the Napf mountain (Swiss plateau). Eclogae Geologicae Helvetiae, 89, 789-809.

Weidmann, M. (1974). Sur quelques gisements de vertébrés dans le Quaternaire du canton de Vaud. Bulletin de Géologie Lausanne, 72, 9-18.

Welten, M. (1972). Das Spätglazial im nördlichen Voralpengebiet der Schweiz-Verlauf, Floristisches, Chronologisches. Berichte der Deutschen Botanischen Gesellschaft, 85, 69-74.
Welten, M. (1982). Pollenanalytische Untersuchungen im Jüngeren Quartär des nördlichen Alpenvorlandes der Schweiz. Beiträge zur Geologischen Karte der Schweiz, NF, 156, 1-174.

Welten, M. (1988). Neue pollenanalytische Ergebnisse über das jüngere Quartär des nördlichen Alpenvorlandes der Schweiz (Mittel und Jungpleistozän). Beiträge zur Geologischen Karte der Schweiz, NF, 162, 1-40. 